\title{
What Is the Role of Training and Job Satisfaction on Turnover Intentions?
}

\author{
Khawaja Jehanzeb $^{1,2}$, Abu Bakar Abdul Hamid ${ }^{1}$ \& Anwar Rasheed ${ }^{1,2}$ \\ ${ }^{1}$ Faculty of Management, Universiti Teknologi Malaysia, UTM Skudai, Johor, Malaysia \\ ${ }^{2}$ Department of Management, College of Business Administration, King Saud University, Riyadh, Saudi Arabia \\ Correspondence: Khawaja Jehanzeb, Faculty of Management, Universiti Teknologi Malaysia, UTM Skudai, \\ 81310 Johor, Malaysia. E-mail: jehanzeb82@yahoo.com
}

Received: December 29, 2014

Accepted: February 15, 2015

Online Published: February 25, 2015

doi:10.5539/ibr.v8n3p208

URL: http://dx.doi.org/10.5539/ibr.v8n3p208

\begin{abstract}
The literature of fast food franchises in Saudi Arabia has reported a lack of research on the topic of employee training. This study pursues to add literature and findings in fast food franchises sector by examining the impact of effective training and coworker support for training on turnover intentions among the employees of fast food franchises in Saudi Arabia. A total number of 350 questionnaires were distributed among the employees working in different fast food franchises of Saudi Arabia, out of which 278 were returned and finally 250 questionnaires were selected for data analysis. The data was collected by source of a structured questionnaire with a total number of 25 questions. In which 10 questions were dedicated to training effectiveness, 3 questions were dedicated to coworker support for training, 8 questions were dedicated to job satisfaction, and 4 were dedicated to turnover intentions of employees. The results described a strong positive relationship between effective training program and job satisfaction, and coworker support for training and job satisfaction. However, there is a negative relationship found between job satisfaction and employees' turnover intentions in fast food franchises of Saudi Arabia. The result of the study has significant decision-making suggestions for franchisers regarding how to decrease turnover intentions of employees by providing them efficient training programs and supportive working environment. Training programs not only increase the value of employees but also the effectiveness of the business.
\end{abstract}

Keywords: coworker, franchising, satisfaction, Saudi Arabia, training, turnover intentions

\section{Introduction}

The most important benefit in buying a franchise is training and getting the practical skill (Price, 1993; Choo \& Bowley, 2007). In all franchises models, it is required for the franchise to deploy a trainer for employees' training. Franchise sector is required to develop and apply significant administrative tools to enhance the performance of their employees (Sayler, 2003). The intelligent franchisers always give high preferences to employees' training as they know training will provide better results to employees and franchise (Larson, 2003). Training is defined as a planned activity taken by the organization to transfer the job knowledge and skills, and improve the attitude and behavior of employees which is consistent with the organizational goals (Noe, 2008). Organizations that provide training to their employees have shown high concern for the commitment to their customer services (Babakus, Yavas, Karatepe, \& Avci, 2003). Moreover, it has been suggested that training programs for employee facilitate them in updating their skills, knowledge, highly dedication, and job satisfaction (Bushardt \& Fretwell, 1994). McDonald's claimed that low level of employee training increases high level of employee turnover, and a good training produces positive impacts on employee retention (Thomas, Lashley, \& Eaglen, 2000). Employee participation in internal and external trainings is useful for the organizations and employees (Burke, 1995). Employees who get superior value in official training programs are comparatively found more satisfied with the job, which directed the employee to feel better understanding to the organization (Burke, 1995). To retain such competent employees, it is required for the organizations to care about their job satisfaction and retention (Jehanzeb \& Bashir, 2013).

Mostly fast food franchises hire the employees at the age of high school and college because of this they have high turnover rate as young employees move from one job to another job (DiPietro, 2003). Training program helps the organizations to achieve the desired performance, and demonstrate return on investment that is 
challenging for training personnel in the fast food sector. Moreover, to being affected by high employee turnover fast food franchises also have the problem for attracting skilled employees. Training and development programs are significant for attracting and retaining skilled and competent employees. Fast food sector has tough market competition as the customers have a number of choices to select according to the quality of services (DiPietro, 2003). A number of surveys have been established to calculate the result of employees' training, such as how much training needed, how training will be provided, and who will get the training. It is also trying to measure the achievement of training efficiency (Joyce, Gittleman, \& Frazis, 2000). The review of literature on fast food franchises has reported a lack of academic research on the topic of employee training (Choo \& Bowley, 2007). Most of the research on training in franchises has considered as a whole package for the franchise (Alden \& Dant, 1990). To address this research gap, researcher proposed to examine the impact of training on turnover intentions of employees among fast food franchises of Saudi Arabia.

In the region of Middle East, franchising has significant growth with a growing number of international companies which are pursuing to create their presence in this region. The franchising project describes that 50\% of worldwide retail business with an aggregate value of $\$ 9$ billion, out of which 5\% is characterized by the Middle East (Shujauddin, 2009). In last five years, fast food franchise market in Saudi Arabia has observed a tremendous growth with different American, European and regional popular franchises, such as McDonalds, Burger King, KFC, Pizza Hut, Subway, Dominos, and Hardee's. It is expected that Saudi Arabia represents a multi-billion dollar market for franchising with a projected value of $\$ 1.3$ billion in annual fees and royalties, and estimated to increase with the average of $12-15 \%$ every year (Shujauddin, 2009). The franchise models are mainly dedicated in the field of restaurant, food, beverage and retail.

Saudi Arabia is a key manufacturer and exporter of oil with largest oil reserve in the world (Jehanzeb, Rasheed, $\&$ Rasheed, 2013). The government of Saudi Arabia plays a significant role in economic development of the country. Government wants to expand its national income by encouraging the private sector to invest in the economy. Franchising is perceived to be a perfect business model for small and medium-sized enterprises (SME) in Saudi Arabia (Shujauddin, 2009). Saudi Arabia is restructuring its economy to adopt new trends in global marketplace, such as small and medium-sized enterprises (SMEs) including franchises. To effectively manage the employee is becoming serious concern for small business which is required for the business success (Oakland \& Oakland, 1998). Therefore, it is suggested that this research has practical implication for the owners of SMEs and fast food franchises to effectively deploy training programs to decrease turnover intentions of employees.

\section{Training Practices in Saudi Arabia}

The Government of Saudi Arabia support workplace training and frequently implements different laws on franchises of multinational organizations for skills development (Jehanzeb et al., 2013). The regional chambers of commerce and industry is enforcing for the training of Saudi labor force by offering them specific training programs. The chambers of commerce and industry provides support to young Saudi workforce to make them qualified to work in private sector, which is out of their approach without the assistance of Saudi government (Al-Asmari, 2008). Jeddah Chamber of Commerce and Industry (JCCI) every year organized about 130 training courses and seminars to fulfill requirement of Saudi workforce to work in private sector. These training programs were established after identifying the demand of private sector; such training programs include customs clearance, office management, marketing, maintenance, and sales (Saudi Embassy; USA, 1997).

A significant improvement has been directed in the field of technical and vocational training through development of highly experienced employees and well-equipped training organizations (Al-Asmari, 2008). The skills and abilities of young Saudi can be increased by providing them training opportunities which will help them to get the job in business market. In Saudi organizations employee turnover is high, specifically, in the private sector (Achoui \& Mansour, 2007). They suggested that organizations are not facilitating for the retention of their employees. Similarly, one more study recommended that employee development strategies have taken a significant place in the field of human resource development by providing them higher education, and precise technical and vocational training programs (Al-Souhem, 1996).

\section{Rationale of the Study}

Saudi Arabia is the leading business market in the Arabian Gulf, and franchising trend is continuously growing in different business sectors. Saudi Arabia is an attractive market for industry of franchising with per capita of $\$ 18,531$ which is up to now at its highest level (Shujauddin, 2009). Generally, young generation of Saudi Arabia wants to start their own businesses as most of them have studied and traveled abroad where they have experienced the taste of Western food. Consequently, this notion leads to the growth of businesses and franchises 
in the market of Saudi Arabia. The industry resources of Saudi Arabia described that fast food franchises are holding more than $60 \%$ of the total franchise market in which $70 \%$ franchises are American (Shujauddin, 2009). Today Saudi Arabia is facing shortage of skilled labor force due to its high economic growth over the past decade. As a result, small and medium-sized enterprises (SMEs), particularly franchises, are facing immense difficulties in recruiting and retaining of their employees. The management of skilled workforce is gradually becoming a major issue for small businesses which are striving for success (Oakland \& Oakland, 1998). The available literature describes a true need for a study which will help the managers to retain their skilled employees by providing them effective training and supportive working environment.

\section{Literature Review and Hypotheses Development}

\subsection{Turnover Intentions}

Turnover refer to "the ratio of the number of organizational members who have left during the period being considered divided by the average number of people in that organization during the period" (Price, 1977). Employees who are dissatisfied with their jobs are more likely to leave the organization than satisfied employee (Mobley, 1997). To strengthening the job satisfaction of employee is helpful in decreasing turnover intentions (Muchinsky, 2000). Fast food franchises are trying to provide training to their new and existing employees. However, fast food franchises have high turnover rate as they hire young employees who leave their job and move for another (DiPietro, 2003). It has been suggested that in fast food sector turnover rate of hourly and salaried employees was more than $150 \%$ annually (Ebbin, 1999). It is a big challenge for training department to assure that training is producing desire outcome and delivering return on investment in the fast food sector (DiPietro, 2003).

The research studies on fast food sector suggested a positive relationship between customer satisfaction and profits over time (DiPietro, 2003). Earlier researches recommended that there is a negative relationship between job satisfaction and turnover intentions (Rahman, Naqvi, \& Ramay, 2008). A study conducted in private sector of Saudi Arabia suggested that there is a negative relationship between training and turnover intensions (Jehanzeb et al., 2013). These studies have also signified that availability of training and education programs are significant factors in enhancing job satisfaction, and reducing turnover intentions of employees (Bartlett, 1999). Similarly, a study recommended that training has positive relationship with job satisfaction and organizational commitment, which later impact on employee retention (Lam \& Zhang, 2003).

\subsection{Effective Training Program}

The key components of training usually analyze its needs, organizing, delivery and effectiveness. The impact of employees' involvement in training has received inadequate research. To get the return on investment it is required to evaluate the training program (Warr, Allan, \& Birdi, 1999). Most of training programs considered as increasing profitability, however, most of small business failed to satisfactorily assess their training programs (Santos \& Stuart, 2003). It is also significant for the organizations to measure the effectiveness of training program (Reid \& Barrington, 1997). However, only 9\% of the organizations measure the effectiveness of training program and positive outcomes which are associated with it (Van Buren \& Erskine, 2002).

Kirkpatrick provide four level of hierarchy model to evaluate the training program which is reaction, behaviour, learning and results. In Kirkpatrick's model, Level 1 (Reactions) measures how employees has reacted to the training, trainer, course, and learning environment. Every training program must be evaluated at this level to response the queries concerning the trainees' perceptions and reactions towards training. However, negative reactions of the employees decrease the possibility of learning (Griego \& Orlando, 2004). Level 2 (Learning) measures what employees have learned from the training and it assesses the degree to which employees have improved their knowledge, skills and attitudes. Level 3 (Behaviour) measures whether employee applied or transfer what they learn from training. Level 3 emphases on the trainees' capability to transfer the learning on the job. Finally, Level 4 (Results) measures whether the application of training is achieving measurable financial results. This evaluation measures the accomplishment of the training program in terms that managers can understand the improved production, increased sales, reduced costs, enhanced quality, higher profits, positive changes in the employees' behaviours (Griego \& Orlando, 2004).

For the effectiveness of a training program it required for the organization to select the right trainer, and training should be appropriate in enhancing to specific job skills (Carolina, 2004). Organizations are using different methods to deliver training program. It is important that organizations should understand which training method will produce better results which are based on the objectives and goals of the origination. Kirkpatrick (1987) suggested criteria for effective training program established on employees' satisfaction with training, knowledge obtain from training, different behaviors of employees on the job, and improved organizational performance. In 
many organizations training is a method for increasing employees' satisfaction and decreasing turnover intentions. Effective training program helps in increasing job satisfaction (Sahinidis \& Bouris, 2008; Osca et al., 2005), customer satisfaction (Rust, Stewart, Miller, \& Pielack, 1996) and reduces employees' turnover intentions (Harris, 1990). A research recommended that there is a positive relationship between training and job satisfaction, and particularly, the employees who participate in training programs are more satisfied than those who did not (Patrick \& Owens, 2006). Referring to the earlier discussion we can suggest that effective training program will positively impact on job satisfaction of employees. This leads to the following hypotheses:

H1. There is a positive relationship between effective training program and job satisfaction.

\subsection{Coworker Support for Training}

Coworker support can be refers as, employees help each other in their job tasks by sharing knowledge and skill, as well as providing assistance and support at workplace (Zhou \& George, 2001). The relationship between coworker and organizational productivity has earned little consideration than the relationships between subordinates and supervisors (Wang, 2008). Earlier researches highlighted the potential benefits for the organizations by developing a working environment in which coworker support in training program. "Anyone who has ever held a job knows that if he does not get along with his coworker the job is unsatisfactory" (Blum \& Naylor, 1968, p. 378). Shah and Jehn (1993) argued that coworker support may have significant results on the performance of employees. It is recommended for the organizations to develop an environment in which employees can create and maintain a supportive relationship with each other (Chiaburu \& Harrison, 2008). Organizations are trying to enhance the collegial support within the organizations, and help the employees to develop their intra-organizational network resources (Raabe \& Beehr, 2003). Coworker support can be described as the degree to which employees perceive that their coworkers care about their well-being and value their input in the job task (Eisenberger, Stinglhamber, Vandenberghe, Sucharski, \& Rhoades, 2002).

Today researchers are paying more attention on the topic of coworker support for training due to its positive effects at workplace. The positive social relationship at workplace may help in increasing job satisfaction and well-being of the employees (Hodson, 1997). Coworker support at workplace is significant to the overall satisfaction of the employees with their jobs (Seers, McGee, Serey, \& Graen, 1983). A study recommended that there is a positive relationship between satisfaction with coworker and job satisfaction (Scarpello \& Campbell, 1983). The earlier studies argued that coworker' support for training is significant for transferring the new learned skills on the job. Employees who have supportive colleagues are more satisfied with their jobs than those who have not. However, in a study negative relationship found between satisfaction with coworker and employees' turnover intentions (Zedeck, Jackson, \& Summers, 1983). According to the earlier discussion we can propose that by providing a supportive working environment at workplace in which employees help each other in improving their skills will help them in increasing job satisfaction. Therefore, this leads us to the following hypotheses:

$\mathrm{H} 2$. There is a positive relationship between coworker support for training and job satisfaction.

\subsection{Job Satisfaction}

Job satisfaction can be define as "an attitude that individuals have about their jobs, results from their perception of jobs and the degree to which there is a good fit between individuals and organization" (Ivancevich, Olekalns, \& Matteson, 1997, p. 91). Employee job satisfaction refers to overall effectiveness of his/her work associated experience that is influenced by ideas, belief and value of the individuals (Chan, Pan, \& Lee, 2004). Researchers working on organizational studies are trying to observe why some of the employees are satisfied with their jobs than others (Ellickson, 2002). Job satisfaction is an important factor, and one of the serious issues for many organizations. It is a set of constructive feelings and emotions which employees analyze for their work (Pak, 2007). A well-recognized approach to describe job satisfaction is as employee fit with their organization (Ellickson, 2002). This proposes that if work environment is satisfying employee's needs, beliefs and individual distinctiveness, such employees will be more satisfied with their job and organization. A number of researches have originated job satisfaction as result of enhancing job performance (Iaffaldano \& Muchinsky, 1985; Mangione \& Quinn, 1975), decreasing absenteeism (Steers \& Rhodes, 1978; Clegg, 1983) and minimizing turnover (Mobley, Griffeth, Hand, \& Meglino, 1979; Freeman, 1978). Therefore, organizations are enhancing job satisfaction of employees by providing them training programs. Hence, this leads us to the following hypotheses:

$\mathrm{H} 3$. There is a negative relationship between job satisfaction and turnover intentions.

\subsubsection{Job Satisfaction as a Mediating Variable}

Job satisfaction has been described in most of the literature as a mediator between the relationship of training 
and turnover intentions (Kolarova, 2010). Some of the studies have recommended that providing training opportunities to employees will lead to higher level of job satisfaction (Pare \& Tremblay, 2007; Georgellis \& Lange, 2007, Edgar \& Geare, 2005). A study conducted in the Dutch pharmacy assistants found a negative relationship between training and employees' turnover intentions mediated by job satisfaction (Koster, Grip \& Fouarge, 2009). Similarly, Cheng and Waldenberger (2013) conducted a study to examine the relationship between training expectations and turnover intentions mediated by job satisfaction among Chinese employees. The study described that employees display different expectations with regard to the content, program design and training outcome. The results recommended that there is a negative relationship between training and turnover intentions while mediated by job satisfaction. Furthermore, employees' expectation about specific training skills and operational factors decreases turnover intentions.

The concept of job satisfaction has been described as an affective attachment to the job that resulted from assessment of actual outcomes with those which are desired and expected (Cranny, Smith \& Stone, 1992). A study recommended that coworker support for training has a negative relationship with turnover intentions (Newman, Thanacoody, \& Hui, 2011), and positive relationship with job satisfaction (Baruch-Feldman et al., 2002). Similarly, a negative relationship found between job satisfaction and turnover intentions of employees (Firth et al., 2004). A number of studies have also analyzed the mediating role of job satisfaction (i.e. Yousef, 2002; Wouter, 2009; Kuo, Lin, \& Li, 2013). Hence, we can assume that job satisfaction will mediate the relationship between coworker support for training and turnover intentions. Therefore, this leads us to the following hypotheses:

H4. Job satisfaction will mediate the relationship between effective training program and turnover intentions.

H5. Job satisfaction will mediate the relationship between coworker support for training and turnover intentions.

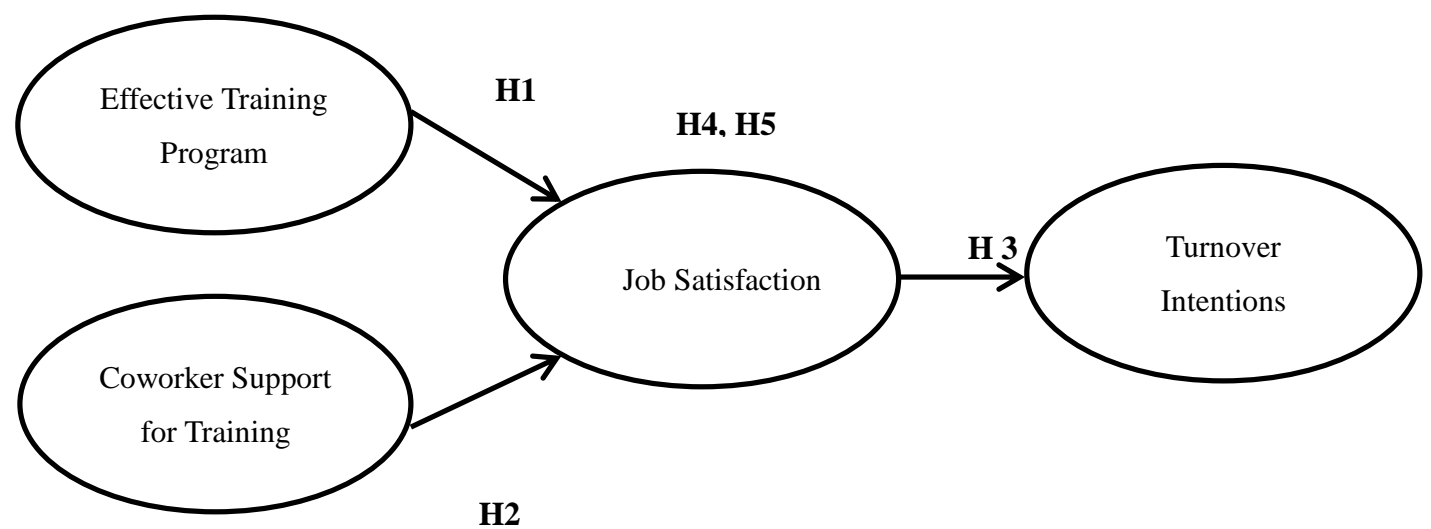

Figure 1. Proposed model of the study

\section{Research Methodology}

\subsection{Sample and Procedure}

The field research was conducted over a period of three months from September to December 2013. For data collection different local and international fast food franchises were selected from major cities of Saudi Arabia, such as Riyadh, Dammam, Khobar and Jeddah. The data was personally collected, and a total number of 350 questionnaires were distributed among the employees working in different fast food franchises. However, 278 questionnaires were returned, out of which 250 questionnaires were lastly nominated for data analysis. The response rate of the questionnaires was almost $71 \%$. Respondents were randomly selected from the list of full-time employees working on different managerial and non-managerial positions. All of the respondents were male because of cultural limitations. In all the selected franchises training was available for the employees. A cover letter was also issued to respondent describing significance of this study, and all participants were encouraged to respond the questions fairly.

\subsection{Measures}

The data was collected by means of a structured questionnaire in which 10 items were dedicated to effectiveness of training program which were adapted from the study of Kirkpatrick (1994). Coworker support for training was 
measured by 3 items scale adapted from Noe and Wilk (1993). 8 items were dedicated to job satisfaction which was adapted from the study of Porter, Crampton, and Smith (1976). Turnover intention was measured with 4 items scale adapted from the study of Farh, Tsui, Xin, and Cheung (1998). The statements of the questionnaire required the respondents to rate the importance of each statement on a five-point likert scale where 1 represents "strongly disagree", 2 "disagree", 3 "Neutral", 4 "agree" and 5 "strongly agree".

\subsubsection{Quality of the Measurement Scales}

To evaluate the reliability of the scales confirmatory factor analysis (CFA) was conducted. Churchill (1979) recommended that items which are not load well onto their corresponding constructs should drop from further consideration. The final question items which was used for analysis and their cross loadings and reliability estimates are shown in Table 1. The CFA stated a good fit of both data and null model as can be seen in Table 1 $\left[_{(483)}^{2}=889.85, \mathrm{p}<0.01\right.$; normed fit index $(\mathrm{NFI})=0.87$; non-normed fit index $(\mathrm{NNFI})=0.93$; comparative fit index $(\mathrm{CFI})=0.93$, goodness-of-fit index $(\mathrm{GFI})=0.84$; root mean square error of approximation $(\mathrm{RMSEA})=$ 0.05]. These findings confirmed the quality of research scales which leads to the phase of hypothesis testing.

Table 1. Measurement scales and results of confirmatory factor analysis

\begin{tabular}{|c|c|}
\hline Items & Factor Loadings \\
\hline \multicolumn{2}{|l|}{ Effective Training Program } \\
\hline 1. The trainer was well prepared and helpful. & $0.77^{*}$ \\
\hline 2. I was satisfied with the support offered by the trainer. & $0.82 *$ \\
\hline 3. The objectives of the training were relevant to my job. & $0.87 *$ \\
\hline 4. I was well informed about completing each module of the training program. & $0.82 *$ \\
\hline 5. The assessments used in the training were fair. & $0.69 *$ \\
\hline 6. I accomplished all objectives of the training. & $0.93 *$ \\
\hline 7. I would be able to apply on my job, what I learned in the training program. & $0.78 *$ \\
\hline 8. I found the overall training program was very challenging. & $0.88 *$ \\
\hline 9. The training program fulfilled my expectations. & $0.67 *$ \\
\hline 10. The activities in the training program provide me sufficient practices. & $0.65 *$ \\
\hline \multicolumn{2}{|l|}{ Coworker Support for Training } \\
\hline 1. My coworkers assist me to apply new skills and knowledge on the job. & $0.84 *$ \\
\hline 2. My coworkers support me in learning new skills during the training program. & $0.94 *$ \\
\hline 3. My coworkers help me to develop the skills which I have learned in the training program. & $0.92 *$ \\
\hline \multicolumn{2}{|l|}{ Job Satisfaction } \\
\hline 1. I feel proud to tell others that I am working with this organization. & $0.87 *$ \\
\hline $\begin{array}{l}\text { 2. I am willing to put in a great deal of effort beyond one normally expected in order to he } \\
\text { successful. }\end{array}$ & $0.70^{*}$ \\
\hline 3. I feel that my own and organization's values are similar. & $0.65 *$ \\
\hline 4. This organization really inspires the best in me in the way of job performance. & $0.78^{*}$ \\
\hline 5. I talk to my friends about my organization as a great place to work. & $0.83 *$ \\
\hline 6. Employees of my organization want to have a long term relationship with it. & $0.82 *$ \\
\hline 7. I participate in the development process of the organization. & $0.85 *$ \\
\hline 8. This is the best organization to work. & $0.81 *$ \\
\hline \multicolumn{2}{|l|}{ Turnover Intentions } \\
\hline 1. I often think of quitting my present job. & $0.82 *$ \\
\hline 2. I may leave this organization and work for another in the next year. & $0.84 *$ \\
\hline 3. I plan to stay in this organization to develop my career for a long time. & $0.81 *$ \\
\hline 4. I may not have a good future if I stay with this organization. & $0.91 *$ \\
\hline
\end{tabular}

Note. ${ }^{2}{ }_{(483)}=889.85 ; \mathrm{GFI}=0.84 ; \mathrm{CFI}=0.93 ; \mathrm{NFI}=0.87 ; \mathrm{NNFI}=0.93 ; \mathrm{RMSEA}=0.05 . * p<0.01$.

GFI = goodness-of-fit index, CFI = comparative fit index, NFI, normed fit index, NNFI = non-normed fit index, RMSEA = root mean square error of approximation. 


\subsection{Demographics}

The gender of the respondents shows that there were $100 \%$ male because of Saudi society has some limitations for female to work in this sector. However, in the term of age, 58.8\% of the respondents were of age group from 21-30 years and 35.3\% belong to age group 31-40 years. On average respondents were working with the franchises from last 2-5 years and the respondents were $4.1 \%$. The ethnic group of respondent, $13.5 \%$ respondents were Saudis and remaining $86.5 \%$ were non-Saudis, who were working in the fast food franchises. Low participation of Saudi citizens in this sector is expected because majority of Saudi citizens prefer to work in the public sector organizations.

\subsection{Results and Discussion}

Table 2 describe that standardized Cronbach's alpha for each of the variables which shows suitable and acceptable internal consistency reliability coefficients for all the scales, as it was greater than .78 (Nunnally, 1978). However, Table 2 presented the correlation between selected variables, such as effective training, coworker's support for training, job satisfaction and the turnover intentions of employees. Analysis of the data shows that effective training program and coworker support for training are positively correlated $(\mathrm{r}=.53, \mathrm{p}$ $<.01)$. However, Table 2 illustrated the positive correlation between effective training and job satisfaction of employees $(\mathrm{r}=0.52, \mathrm{p}<.01)$.

Table 2. Mean, standard deviations and Pearson correlations

\begin{tabular}{|c|c|c|c|c|c|c|}
\hline Variables & Mean & S.D & ET & CST & JS & TI \\
\hline ET & 3.54 & .89 & $(.90)$ & & & \\
\hline CST & 3.67 & 1.00 & $.53 * *$ & $(.90)$ & & \\
\hline JS & 3.62 & .94 & $.52 * *$ & $.55^{* *}$ & (.79) & \\
\hline TI & 2.93 & 1.24 & $-.29 * *$ & $-.25^{*}$ & $-.38 * *$ & $(.79)$ \\
\hline
\end{tabular}

Note. $\mathrm{ET}=$ Effective Training; JS= Job Satisfaction; CST= Coworker Support for Training; TI= Turnover Intention **Correlation is significant at the 0.01 level ( 2 tailed); *Correlation is significant at the 0.05 level ( 2 tailed).

Table 3. Mediation analysis

\begin{tabular}{cccccc}
\hline Dependent Variable & Independent Variable & $\boldsymbol{\beta}$ & S. E & t - value & Sig. \\
\hline \multirow{2}{*}{ JS } & ET & .34 & .099 & 3.398 & .001 \\
& CST & .35 & .088 & 3.960 & .000 \\
\hline \multirow{2}{*}{ TI } & ET & -.32 & .157 & -2.054 & .043 \\
& CST & -.15 & .139 & -1.087 & .028 \\
\hline TI & JS & -.50 & .122 & -4.11 & .000 \\
\hline \multirow{2}{*}{ TI } & ET & -.18 & .161 & -1.155 & .252 \\
& CST & -.01 & .145 & -.0670 & .947 \\
& JS & -.41 & .154 & -2.629 & .010 \\
\hline
\end{tabular}

Note. $\mathrm{CST}=$ Coworker Support for Training; ET = Effective Training; JS = Job Satisfaction; TI = Turnover Intentions.

Hypothesis 1 describes that effective training and job satisfaction are positively related. The results of regression analysis in Table 3 demonstrate that regression between effective training and job satisfaction is highly significant $(\beta=.34$, t-value $=3.39, \mathrm{p}=.001)$. Thus, hypothesis 1 is accepted. The results proposed that effective training programs are very important and positively correlated with job satisfaction in the fast food franchises of Saudi Arabia. Therefore, results indicate that effective training program is important for the job satisfaction of employees. Hypothesis 2 predicted the significant relationship between coworker support for training and job satisfaction. Results of regression analysis in Table 3 confirmed that coworker support for training is positively and significantly related with job satisfaction $(\beta=.35$, t-value $=3.96, \mathrm{p}<.001)$. Thus, hypothesis 2 is accepted. The research described employees of fast food franchises feel comfortable and having positive expectation based 
on appreciation of support from coworker. The findings of our research confirm the outcomes of earlier studies (Scarpello \& Campbell, 1983). Hypotheses 3 proposed that job satisfaction is negatively related with turnover intentions of employees. Table 3 shows that job satisfaction and turnover intentions has significant negative relation $(\beta=-.50, p<.001)$. Results are consistent with the findings of earlier researchers (Rahman et al., 2008).

Hypotheses 4 and 5 predicted that job satisfaction mediates the relationship between effective training and employee turnover intentions and similarly, between coworker support for training and turnover intentions respectively. According to Baron and Kenny (1986), three criteria should be met to test the mediation. First, there must be a direct relationship between independent variable and dependent variable. Table 3 shows that effective training is significantly related to turnover intentions $(\beta=-.32, p<.05)$ as well as significant relationship between coworker support for training and turnover intentions $\beta=-.15, p<.05)$.

Second, there must be significant relationship between independent variable and mediator. Effective training and coworker support for training are significantly related to job satisfaction (Hypotheses 1 and 2). Third, mediating variable must be significantly related to dependent variable. Results show that job satisfaction is significantly related to turnover intentions (Hypothesis 3). All three of these preconditions were supported for testing the mediation. Finally, for full mediation, the relationship between independent variable and dependent variable must no longer be significant when regressed together with mediator. As shown in Table 3, the impact of effective training on turnover intentions is fully mediated by job satisfaction as job satisfaction becomes significant $(\beta=-.41, \mathrm{p}<.05)$, but effective training and turnover intentions relationship become insignificant ( $\beta$ $=-.18, \mathrm{p}=.25$ ). Similarly, job satisfaction fully mediates the relationship between coworker support for training and turnover intentions $(\beta=-.01, \mathrm{p}=.94)$. Thus hypotheses 4 and 5 are accepted.

\section{Future Recommendations}

Future research on this topic needs more detailed empirical research in fast food sector of Saudi Arabia that will help the researchers to understand what are the other factors that effects on job satisfaction and turnover intentions. Secondly, future research can be conducted by adding one more variable of supervisor support for training to examine the relationship with job satisfaction. Thirdly, before generalized these results further research is required across various geographical settings and industries (Schuler, Dowling, \& De Cieri, 1993). Fourthly, our research recommends examining the moderating influence from cultural variables (i.e. collectivism, power distance, and traditionality) on the relationship between training and job satisfaction (Newman, Thanacoody, \& Hui, 2011). Finally, it is significant for future studies to validate the findings of this study by a longitudinal study. The longitudinal study could be more suitable than cross-sectional study for establishing theoretical and empirical data (Chiaburu, Dam, \& Hutchins, 2010).

\section{Limitations}

In this study two key limitations were observed. First, while investigating the research in depth it provides a detail understanding of one solitary study which is specific to fast food franchises and later, it is limited to generalization of this study. Secondly, the outcomes of this research require other explanations because of research environment, and as well as the explanation of the respondents. Thirdly, while conducting this research, researcher only approached to male employees, as female are not allowed to work in this sector due to cultural limitation. Cheater (1987) suggested that we cannot make ourselves free of this subjectivity nor we should wish but we ought to be aware of it. More significantly the analysis of knowledge and experience of employees towards training activities are facilitate the researcher to improve an understanding the range of other factors that influence on effectiveness of training.

\section{Conclusion}

In this study the relationship between effective training program and coworker support for training with job satisfaction; and job satisfaction with turnover intentions was examined. The results recommended that effective training program and coworker support for training are positively related to the job satisfaction (Choo \& Bowley, 2007; Baruch-Feldman, Brondolo, Ben-Dayan, \& Schwartz, 2002; Seers, McGee, Serey, \& Graen, 1983). In line with other researchers, negative relationship found between job satisfaction and turnover intentions (Mobley, Griffeth, Hand, \& Meglino, 1979; Freeman, 1978; MacIntosh, \& Doherty, 2010). However, job satisfaction mediates the relationship between effective training program, coworker support for training, and turnover intentions. Difference in culture and working environment in Saudi Arabia must be considered while comparing the results of similar studies in other countries. Culturally designed training can be resulted more effective to impact positively on job satisfaction along with negatively impact on turnover intentions. It is also required for fast food franchises of Saudi Arabia to provide training opportunities to their employees which will help in reducing their turnover rate. 
This study provides practical implication for small business and fast food franchises. The retail franchise industry is categorized by staffs who are generally employed on the basis of part-time. Employees of this sector has ignored by most of the franchisers which are a potential source for future managers or franchisees (Choo \& Bowley, 2007). This study will improve our understanding regarding the analytical components of an effective training program in terms of trainer experience, design of course and learning experience, and coworker support for training might possess to deliver job satisfaction. Furthermore, the results of the study recommended that employees' turnover intensions can be decreased by providing them effective training program and a supportive working environment.

\section{References}

Achoui, M., \& Mansour, M. (2007). Employee turnover and retention strategies: Evidence from Saudi Companies. International Review of Business Research Papers, 3(3), 1-16.

Al-Asmari, M. G. H. (2008). Saudi labor force: Challenges and ambitions. JKAU: Arts \& Humanities, 16(2), $19-59$.

Alden, P., \& Dant, R. P. (1990). Perceived advantages of the franchise option from the franchisee perspective: Empirical insights from a service franchise. Journal of Small Business Management, 28(3), 46-61.

Al-Souhem, K. A. (1996). The attitudes of Saudi manager towards human resource management in selected firms. $\mathrm{PhD}$ thesis, University of Wales.

Babakus, E., Yavas, U., Karatepe, O., \& Avci, T. (2003). The effect of management commitment to service quality on employees' affective and performance outcomes. Academy of Marketing Science, 31(3), 272-287. http://dx.doi.org/10.1177/0092070303031003005

Baron, R. M., \& Kenny, D. A. (1986). The moderator - mediator variable distinction in social psychological research: Conceptual, strategic, and statistical considerations. Journal of Personality and Social Psychology, 51, 1173-1182. http://dx.doi.org/10.1037/0022-3514.51.6.1173

Bartlett, K. R. (1999). The relationship between training and organizational commitment in the health care field. University of Illinois at Urbana- Champaign.

Baruch-Feldman, C., Brondolo, E., Ben-Dayan, D., \& Schwartz, J. (2002). Sources of social support and burnout, job satisfaction and productivity. Journal of Occupational Health Psychology, 7(1), 84-93. http://dx.doi.org/10.1037//1076-8998.7.1.84

Blum, M. L., \& Naylor, J. C. (1968). Industrial psychology: Its theoretical and social foundations (3rd ed.). New York: Harper \& Row.

Burke, R. (1995). Benefits of formal training courses within a professional setting. The Journal of Management Development, 14(3), 3-14. http://dx.doi.org/10.1108/02621719510078920

Bushardt, S. C., \& Fretwell, C. (1994). Continuous improvement through employee training: A case example from the financial services industry. The Learning Organization: An International Journal, 1(1), 11-16. http://dx.doi.org/10.1108/09696479410053395

Carolina Entrepreneurship Club. (2004). Employee training and development. White Paper.

Chan, M. J., Pan, Z. D., \& Lee, L. F. F. (2004). Professional aspirations and job satisfaction: Chinese journalists at a time of change in the media. Journalism and Mass Communication Quarterly, 81(2), 254-73. http://dx.doi.org/10.1177/107769900408100203

Cheater, A. P. (1987). The anthropologist as citizen: The diffracted self. In A. Jackson (Ed.), Anthropology at home (pp. 164-179). Tavistock, London.

Cheng, Y., \& Waldenberger, F. (2013). Does training affect individuals' turnover intention? Evidence from China. Journal of Chinese Human Resource Management, 4(1), 16-38. http://dx.doi.org/10.1108/JCHRM-10-2012-0024

Chiaburu, D. S., \& Harrison, D. A. (2008). Do peers make the place? Conceptual synthesis and meta-analysis of co-worker effects on perceptions, attitudes, OCBs, and performance. Journal of Applied Psychology, 93, 1082-103. http://dx.doi.org/10.1037/0021-9010.93.5.1082

Chiaburu, D. S., \& Tekleab, A. G. (2005). Individual and contextual influences on multiple dimensions of training effectiveness. Journal of European Industrial Training, 29(8), 604-626. http://dx.doi.org/10.1108/03090590510627085 
Chiaburu, D. S., Dam, K. V., \& Hutchins, H. M. (2010). Social support in the workplace and training transfer: A longitudinal analysis. International Journal of Selection and Assessment, 18(2), 187-200. http://dx.doi.org/10.1111/j.1468-2389.2010.00500.x

Choo, S., \& Bowley, C. (2007). Using training and development to affect job satisfaction within franchising. Journal of Small Business and Enterprise Development, 14(2), 339-352. http://dx.doi.org/10.1108/14626000710746745

Churchill, G. A. (1979). A paradigm for developing better measures of marketing constructs. Journal of Marketing Research, 16(1), 64-73. http://dx.doi.org/10.2307/3150876

Clegg, C. W. (1983). Psychology of employee lateness, absence and turnover: A methodological critique and an $\begin{array}{lllll}\text { empirical study. Journal of Applied Psychology, 68(1), } & \text { 88-101. }\end{array}$ http://dx.doi.org/10.1037//0021-9010.68.1.88

Cranny, C. J., Smith, P. C., \& Stone, E. F. (1992). Job satisfaction: How people feel about their jobs and how it affects their performance. New York: Lexington Press.

DiPietro, R. (2003). The effectiveness of managerial training in a fast food restaurant chain. Ph. D. Dissertation, University of Nebraska.

Ebbin, R. (March, 1999). Turnover takes a turn for the better. Restaurants USA.

Edgar, F., \& Geare, A. (2005). HRM practice and employee attitudes: Different measures - different results. Personnel Review, 34(5), 534-549. http://dx.doi.org/10.1108/00483480510612503

Eisenberger, R., Stinglhamber, F., Vandenberghe, C., Sucharski, I. L., \& Rhoades, L. (2002). Perceived supervisor support: contributions to perceived organizational support and employee retention. Journal of Applied Psychology, 87, 565-573. http://dx.doi.org/10.1037/0021-9010.87.3.565

Ellickson, M. C. (2002). Determinants of job satisfaction of municipal government employees. Public Personnel Management, 31(3), 343-358. http://dx.doi.org/10.1177/0160323X0103300302

Farh, J. L., Tsui, A. S., Xin, K. R., \& Cheung, B. S. (1998). The influence of relational demography and guanxi: The Chinese case. Organization Science, 9(2), 1-18.

Firth, L., Mellor, D. J., Moore, K. A., \& Loquet, C. (2004). How can managers reduce employee intention to quit? Journal of Management Psychology, 19(2), 170-187. http://dx.doi.org/10.1108/02683940410526127

Freeman, R. B. (1978). Job satisfaction as an economic variable. The American Economic Review, 68(2), 135-41.

Georgellis, Y., \& Lange, T. (2007). Participation in continuous, on-the-job training and the impact on job satisfaction: Longitudinal evidence from the German labour market. The International Journal of Human Resource Management, 18(6), 969-985. http://dx.doi.org/10.1080/09585190701321112

Griego, O. V. (2004). Assessments and the kirkpatrick model. Retrieved from http://www.home.apu.edu

Harris, J. (1990). Using attitude change to measure affective response: An investigation of voluntary turnover behavior. Unpublished Ph. D. Dissertation, Florida University.

Hodson, R. (1997). Group relations at work. Work and Occupations, 24(4), 426-452. http://dx.doi.org/10.1177/0730888497024004003

Hollenbeck, J. R., \& Williams, C. R. (1986). Turnover functionality versus turnover frequency: A note on work attitudes and organisational effectiveness. Journal of Applied Psychology, 71(4), 606-611. http://dx.doi.org/10.1037/0021-9010.71.4.606

Iaffaldano, M. T., \& Muchinsky, P. M. (1985). Job satisfaction and performance: A meta-analysis. Psychological Bulletin, 97, 251-273. http://dx.doi.org/10.1037//0033-2909.97.2.251

Ivancevich, J. M, Olekalns, M., \& Matteson, M. T. (1997). Organizational behavior and management. Sydney: Irwin.

Jehanzeb, K., \& Bashir, N. A. (2013). Training and development program and its benefits to employee and organization: A conceptual study. European Journal of Business and Management, 5(2), 243-252.

Jehanzeb, K., Rasheed, A., \& Rasheed, M. F. (2013). Organizational commitment and turnover intentions: Impact of employee's training in private sector of Saudi Arabia. International Journal of Business and Management, 8(8), 79-90. http://dx.doi.org/10.5539/ijbm.v8n8p79

Joyce, M., Gittleman, M., \& Frazis, H. (2000). Correlates of training: An analysis using employer and employee 
characteristics. Industrial and Labor Relations Review, 53(3), 443-463. http://dx.doi.org/10.2307/2695968

Kirkpatrick, D. L. (1987). Evaluation of training. In R. L. Craig (Ed.), Training and development handbook: A guide to human resource development (pp. 301-319). McGraw-Hill, New York, NY.

Kirkpatrick, D. L. (1994). Evaluating training programs: The four levels. Berrett-Koehler Publishers, San Francisco, CA.

Kolarova, D. V. (2010). The impact of participation in job training on employee turnover intention and the mediatory function of job satisfaction. Master Thesis, Tilburg University.

Koster, F., de Grip, A., \& Fouarge, D. (2009). Does perceived support in employee development affect personnel turnover? Research Memoranda, Research Centre for Education and the Labour Market, Maastricht University.

Kuo, H. T., Lin, K. C., \& Li, I. (2013). The mediating effects of job satisfaction on turnover intention for long-term care nurses in Taiwan. Journal of Nursing Management, 22(2), 225-233. http://dx.doi.org/10.1111/jonm.12044

Lam, T., \& Zhang, H. Q. (2003). Job satisfaction and organizational commitment in the Hong Kong fast food industry. International Journal of Contemporary Hospitality Management, 15(4), 214-229. http://dx.doi.org/10.1108/09596110310475667

Larson, P. (2003). Frontline training for bottom line results. Franchising World, 35(4), 6-11.

MacIntosh, E. W., \& Doherty, A. (2010). The influence of organizational culture on job satisfaction and intention to leave. Sport Management Review, 13(2), 106-117. http://dx.doi.org/10.1016/j.smr.2009.04.006

Mangione, T. W., \& Quinn, R. P. (1975). Job satisfaction counter-productive behaviour and drug use at work. Journal of Applied Psychology, 60, 114-116. http://dx.doi.org/10.1037/h0076355

Mobley, W. H. (1997). Employee turnover: Causes, consequences, and control. Reading, MA: Addison-Wesley Publishing Company.

Mobley, W. H., Griffeth, R. W., Hand, H. H., \& Meglino, B. M. (1979). Review and conceptual analysis of the $\begin{array}{llll}\text { employee turnover process. Psychological } & \text { Bulletin, } & \text { 86, }\end{array}$ http://dx.doi.org/10.1037//0033-2909.86.3.493

Muchinsky, P. (2000). Psychology applied to work: An introduction to industrial and organizational psychology (6th ed.). US: Wadworth Thompson Learning.

Newman, A., Thanacoody, R., \& Hui, W. (2011). The impact of employee perceptions of training on organizational commitment and turnover intentions: A study of multinationals in the Chinese service sector. The International Journal of Human Resource Management, 22(8), 1765-1787. http://dx.doi.org/10.1080/09585192.2011.565667

Noe, R. A., \& Wilk, S. L. (1993). Investigation of the factors that influence employees' participation in development activities. Journal of Applied Psychology, 78(2), 291-302. http://dx.doi.org/10.1037/0021-9010.78.2.291

Noe, R. A. (2008). Employee Training and Development (4th ed.). New York: McGraw Hill.

Nunnally, J. C. (1978). Psychometric theory (2nd ed.). New York: McGraw-Hill.

Oakland, J. S., \& Oakland, S. (1998). The link between people management, customer satisfaction and business results. Total Quality Management, 9, 185-191. http://dx.doi.org/10.1080/0954412988866

Osca, A., Urien, B., Gonza'lez-Camino, G., Martı'nez-Pe'rez, M. D., \& Martı'nez-Pe'rez, N. (2005). Organisational support and group efficacy: A longitudinal study of main and buffer effects. Journal of Managerial Psychology, 20, 292-311. http://dx.doi.org/10.1108/02683940510589064

Pak, O. G. (2007). The effect of organizational learning on organizational commitment, job satisfaction and work performance. Ph.D. Thesis, University Putra Malaysia.

Paré, G., \& Tremblay, M. (2007). The influence of high-involvement human resource practices, procedural justice, organisational commitment, and citizenship behaviours on information technology professionals'

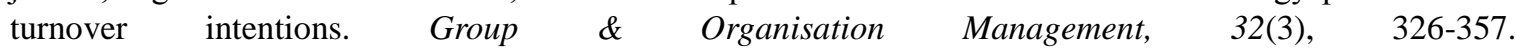
http://dx.doi.org/10.1177/1059601106286875

Patrick, L., \& Owens, Jr. (2006). One more reason not to cut your training budget: The relationship between 
training and organizational out comes. Public Personnel Management, 35(2).

Porter, L. W., Crampton, W. J., \& Smith, F. J. (1976). Organizational commitment and managerial turnover: A longitudinal study. Organizational Behavior and Human Performance, 15, 87-98. http://dx.doi.org/10.1016/0030-5073(76)90030-1

Price, J. (1977). The study of turnover. IA: Iowa State University Press.

Price, S. (1993). Performance of fast-food franchises in Britain. International Journal of Contemporary Hospitality Management, 5(3), 10-16. http://dx.doi.org/10.1108/09596119310040516

Raabe, B., \& Beehr, T. A. (2003). Formal mentoring versus supervisor and co-worker relationships: Differences in perceptions and impact. Journal of Organizational Behavior, 24, 271-293. http://dx.doi.org/10.1002/job.193

Rahman, A., Naqvi, R., \& Ramay, I. M. (2008). Measuring turnover intention: A study of IT professionals in Pakistan. International Review of Business Research Papers, 4(3), 45-55.

Reid, M. A., \& Barrington, H. (1997). Training interventions: Managing employee development (5th ed.). Institute of Personnel and Development, London.

Rust, R., Stewart, G. L., Miller, H., \& Pielack, D. (1996). The satisfaction and retention of frontline employees: A customer satisfaction measurement approach. International Journal of Service Industry Management, 7(50), 62-80. http://dx.doi.org/10.1108/09564239610149966

Sahinidis, A. G., \& Bouris, J. (2008). Employee perceived training effectiveness relationship to employee $\begin{array}{lllll}\text { attitudes. Journal of European Industrial Training } & \text { 32(1), }\end{array}$ http://dx.doi.org/10.1108/03090590810846575

Santos, A., \& Stuart, M. (2003). Employee perceptions and their influence on training effectiveness. Human Resource Management Journal, 13(1), 27-44. http://dx.doi.org/10.1111/j.1748-8583.2003.tb00082.x

Saudi Embassy USA. (1997). Training Saudis for technical and vocational careers.

Sayler, T. (2003). The single most significant event in the life of a franchise relationship. Franchising World, 35(4), 13-15.

Scarpello, V., \& Campbell, J. P. (1983). Job satisfaction: Are all the parts there? Personnel Psychology, 36, 577-600. http://dx.doi.org/10.1111/j.1744-6570.1983.tb02236.x

Schuler, R. S., Dowling, P. J., \& De Cieri, H. (1993). An integrative framework of strategic human resource management. International Journal of Human Resource Management, 4(4), 717-764. http://dx.doi.org/10.1080/09585199300000056

Seers, A., McGee, G. W., Serey, T. T., \& Graen, G. B. (1983). The interaction of job stress and social support: A strong inference investigation. Academy of Management Journal, 26, 273-284. http://dx.doi.org/10.2307/255975

Shah, P. P., \& Jehn, K. A. (1993). Do friends perform better than acquaintances? The interaction of friendship, conflict and task. Group Decision and Negotiation, 2, 149-165. http://dx.doi.org/10.1007/BF01884769

Shujauddin, M. (2009). Saudi Arabia: Franchising market update. Franchising Market Update, 1-5.

Steers, R. M., \& Rhodes, S. R. (1978). Major influences on employee attendance: A process model. Journal of Applied Psychology, 63(4), 391-407. http://dx.doi.org/10.1037//0021-9010.63.4.391

Thomas, R., Lashley, C., \& Eaglen, A. (2000). The benefits of training in leisure retailing: A case study of $\begin{array}{lllll}\text { McDonald's } & \text { restaurants. } & \text { Strategic } & \text { Change, } & 9,\end{array}$ http://dx.doi.org/10.1002/1099-1697(200009/10)9:6<333::AID-JSC505>3.0.CO;2-7

Van Buren, M. E., \& Erskine, W. (2002). The 2002 ASTD State of the Industry Report. Alexandria, VA: ASTD.

Wang, Y. (2008). Emotional bonds with supervisors and co-workers: Relationship to organizational commitment in China's foreign-invested companies. International Journal of Human Resource Management, 19(5), 916-931. http://dx.doi.org/10.1080/09585190801993901

Warr, P., Allan, C., \& Birdi, K. (1999). Predicting three levels of training outcomes. Journal of Occupational and Organizational Psychology, 72, 351-376. http://dx.doi.org/10.1348/096317999166725

Wouter, V. (2009). The mediating effect of job satisfaction and organizational commitment on self-reported performance: More robust evidence of the PSM-performance relationship. International Review of 
Administrative Sciences, 75(1), 11-34. http://dx.doi.org/10.1177/0020852308099504

Yousef, D. A. (2002). Job satisfaction as a mediator of the relationship between role stressors and organizational commitment: A study from an Arabic cultural perspective. Journal of Managerial Psychology, 17(4), 250-266. http://dx.doi.org/10.1108/02683940210428074

Zedeck, S., Jackson, S. E., \& Summers, E. (1983). Shift work schedules and their relationship to health, adaptation, satisfaction, and turnover intention. Academy of Management Journal, 26(2), 297-310. http://dx.doi.org/10.2307/255977

Zhou, J., \& George, J. M. (2001). When job dissatisfaction leads to creativity: Encouraging the expression of voice. The Academy of Management Journal, 44(4), 682-696. http://dx.doi.org/10.2307/3069410

\section{Copyrights}

Copyright for this article is retained by the author(s), with first publication rights granted to the journal.

This is an open-access article distributed under the terms and conditions of the Creative Commons Attribution license (http://creativecommons.org/licenses/by/3.0/). 